graphs, 88 journal essays, 11 edited and coedited books, and 5 contributions to major reference works. Among the essays included in the Festgabe is his admirable "The Slovak Republic, 1939-1945" (originally published in A History of the Czechoslovak Republic, 19181948, edited by Victor S. Mamatey and Radomír Luža, 1973). This and other studies on Slovakia distinguished Hoensch as the sole German historian of that time- and one of the few in the west-who tackled the contentious question of Slovakia's place in the Czechoslovak constitutional system and its breakaway in 1939 to form an independent state, and who dealt with it in an objective way based not on nationalistic or ideological fervor but on careful study of the evidence.

Hoensch's balanced scholarly approach can also be found in his other works: Die Slowakei und Hitlers Ostpolitik: Hlinkas Slowakische Volkspartei zwischen Autonomie und Separation 1938/1939 (1965); Geschichte der Tschechoslowakischen Republik (1966, 1978, 1992 with changed title); Der ungarische Revisionismus und die Zerschlagung der Tschechoslowakei (1967); Dokumente zur Autonomie-Politik der Slowakischen Volkspartei Hlinkas (1984); Das Scheitern der Verständigung. Tschechen, Deutsche and Slowaken in der Ersten Republik 1918-1938 (with Dušan Kováč, 1994; Czech original ,1993); Judenemanzipation-Antisemitismus-Verfolgung in Deutschland, Osterreich-Ungarn, den böhmischen Ländern und in der Slowakei (1999, with Stanislav Biman and L'ubomir Lipták; Slovak edition, 1999).

In their tribute volume, his German colleagues describe Hoensch's approach to teaching and scholarship as follows: "During his academic career, Hoensch displayed an ability to speak in polished phrases, and in addition to an enviably fine memory, he possessed above all the ability and energy to achieve outstanding results, always based on the latest scholarly research" (x).

In addition to his work on Slovakia, Hoensch's publications include many works concerned with Polish and Hungarian history and with medieval Central Europe, as well as the survey Geschichte Böhmens: Von der Slavischen Landnahme bis ins 20. Jahrhundert, which has been revised and updated three times $(1987,1992,1997)$ and deserves translation into English. He also wrote Geschichte Polens (1983, 1990, 1998), and Geschichte Ungarns 1867-1983 (English editions 1988, 1996). His Matthias Corvinus: Diplomat, Feldherr und Mäzen (1998) and Die Luxemburger: Eine spätmittelalterliche Dynastie gesamteuropäischer Bedeutung 1308-1438 (2000) further demonstrate his versatility and astounding productivity. Hoensch served on the UNESCO-launched German-Polish Schoolbook Commission, the German-Czech and the German-Slovak Historical Commissions, and other international cultural bodies. His death at the peak of his powers is a profound loss to the historical profession throughout the world.

STANLEY B. WinTERS New Jersey Institute of Technology April 2001

\title{
Mirra Ginsburg, 1909-2000
}

Mirra Ginsburg died on Long Island on 26 December 2000 at the age of 91 . She was born on 10 June 1909 in the Jewish town of Bobruisk, in Belarus. In the 1920s, her family emigrated to Canada and subsequently to the United States. Ginsburg spoke fondly of her childhood memories of living in a tightly knit, culturally conscious Jewish community of family and friends. As an adult, she lived and worked in New York as a freelance translator and served on translation juries. Ginsburg was a member of the American Literary Translators Association, Authors Guild, Authors League of America, and PEN.

My first meeting with Mirra Ginsburg in her apartment in 1975, on a dreadfully rainy day, was the beginning of a long friendship. I had read her brilliant translations of Aleksei Remizov and wanted to speak to her about the writer, who was the topic of my doctoral dissertation at Yale University. She had just received a Guggenheim Fellowship for her translation work, and my advisor, Victor Erlich, suggested I meet with her. As it turned out, we had so many interests in common that our conversation lasted for a quarter of a century. 
The most striking thing about Ginsburg was her unnerring sense of the right word. Besides native Russian and Yiddish, she had a great sense of literary as well as spoken English. This linguistic sensitivity is what made her translations into an art and what enabled her to know just whom to translate. She would find a talent she was convinced of and could become impassioned about and adopt that person's works as her cause. This was true of Evgenii Zamiatin, as well as of Mikhail Bulgakov and Andrei Platonov. She was instrumental in discovering these writers, who were not yet published in their own country, but who became known in the west, often through her masterful translations, in the late 1960s and early 1970 s. Their works have contributed to the creation of the canon of early Soviet literature and have become indispensable in university courses on the subject.

Ginsburg's translations are considered classic. Many are accompanied by her own introductions, which are incisive and scholarly, but not academic, such as for The Fatal Eggs and Other Soviet Satire (1965 and 1968). She translated the best in Soviet science fiction: The Ultimate Threshold: Anthology of Soviet Science Fiction (1970) and The Air of Mars and Other Stories of Time and Space (1976). Perhaps Ginsburg's greatest contributions are her translations of Zamiatin, which have been reprinted numerous times: The Dragon: Fifteen Stories by Yevgeny Zamyatin (1966; 2d ed., 1976); A Soviet Heretic: Essays by Yevgeny Zamyatin, introduction by Alex Shane (1970); We (1972). Her translations of Bulgakov's prose and plays were also among the first and the best: The Master and Margarita (1967), Flight (1969), The Life of Monsieur de Molière (1970), and Bliss (1985). In 1975 she published one of the earliest translations of a then recently discovered novel by Platonov, The Foundation Pit. And one of her last literary translation projects, a labor of love, was the book containing two short novels by Iurii Tynianov, Lieutenant Kije/Young Vitushishnikov (1991).

Because of her remarkable appreciation for language, she was often intolerant of people who were careless with words. She could argue about a translated text with editors for as long as it took to have it done the right way. She had the courage of her convictions and was undaunted by any obstacles, taking on press editors and pedantic, narrow-minded academics alike. Her friends and associates were often drawn into exquisite arguments, and it was always clear to me that Ginsburg could vanquish any opponent on the ground of verbal art. For this reason, when I needed help translating a difficult phrase in Remizov, for example, I could count on Ginsburg to come to the rescue with exactly the right word or phrase. There was never any doubt about it. The pleasure of these conversations would linger for a long time; these are some of the best memories I have of her.

It is not that "the work was better in translation," but that it was equal to the original to the highest degree possible. Ginsburg had the ability to grasp and convey the most elusive aspect of a writer's work, the nuance of a particular intonation or the quality of oral speech, so important in the work of Zamiatin, Bulgakov, Platonov. This was the great challenge of translating the most literary of twentieth-century Russian writers, who crossed planes of lexical levels and semantic associations and perfected the art of verbal play or punning. Her linguistic abilities are evident in her great translation of Bulgakov's Master and Margarita, a book beloved by many undergraduates, but also in her translation of Fedor Dostoevskii's Notes from the Underground, which was chosen as the text for a one-man stage performance, and in her translations of Zamiatin's plays and of Bulgakov's Bliss, which have also been taken as the basis for many theatrical performances.

Her unconditional belief in the magic of language also led her to become a consummate author and translator of children's books, and she has produced many masterpieces of children's literature. Of the Russian children's writers she loved Daniil Kharms above all, as well as Kornei Chukovskii, with whom she had a long epistolary friendship. She also became exceedingly knowledgeable concerning the folktales of the many ethnic groups in the former Soviet Union, and these formed the basis of her creative retelling of the tales.

As a translator, adapter, and storyteller Ginsburg worked hard to get as close to the roots of the language and the story as possible. For her, translation was an art, and her work is a great testament to that conviction. 